\title{
Classification and Analysis of Criteria Used in the Due Diligence Process
}

\author{
Ma Camino Ramón-Llorens \\ Department of Financial Economics and Accounting \\ Technical University of Cartagena \\ Calle Real, 3 - 30201 Cartagena, Murcia, Spain \\ Tel: 34-868-071-045 E-mail: camino.ramon@upct.es \\ Ginés Hernández-Cánovas (Corresponding author) \\ Department of Financial Economics and Accounting \\ Technical University of Cartagena \\ Calle Real, 3 - 30201 Cartagena, Murcia, Spain \\ Tel: 34-968-325-761 E-mail: gines.hernandez@upct.es
}

Received: November 3, 2011

Accepted: February 1, 2012 Published: March 16, 2012

doi:10.5539/ijbm.v7n6p81

URL: http://dx.doi.org/10.5539/ijbm.v7n6p81

\begin{abstract}
This paper uses a survey dataset of 51 Venture Capital Companies to address a segmentation of the venture capital industry. Our paper yields two specific contributions. First, we analyze in a Continental European bank-based system the most important investment criteria identified by previous empirical literature. Second, we show that existing differences in the use of the investment criteria depend on the existence of asymmetric information problems associated to specific characteristics of the venture capital companies. Knowing what investment criteria are the most important for venture capitalists might help both entrepreneurs to elaborate better proposals, and venture capitalists to improve their decision process and achieve better survival rates.
\end{abstract}

Keywords: Venture capital, Cluster analysis, Screening criteria, Decision-making

\section{Introduction}

Variation in the use of the investment criteria across venture capital companies has received a great deal of attention in recent empirical research. One line of research shows that the use of investment criteria and their relative importance depend on the existence of asymmetric information problems (Barry, 1994; Fried and Hisrich, 1994). A related line of literature suggests that asymmetric information problems as well as the ability and incentives of venture capitalists to overcome those problems are related to characteristics such as the origin of the resources, the use of intuition or the investment strategy (Carter and Van Auken, 1994; Leleux and Surlemont, 2003; Zacharakis and Shepherd, 2001).

One direct implication of the above studies is the existence of a link between the characteristics of the venture capital company and the investment criteria applied during the due diligence. The analysis of this link by classifying venture capital companies according to any specific characteristic imposes an a priori limitation that assumes standard behaviour of venture capitalists just because their companies share one attribute. Instead, we think that investment criteria depend on a wide range of factors which are difficult to control for even if we try to do so in a regression model. In addition, a priori classifications limit the possibility of uncovering associations which are not obvious, but that can be helpful once found, and restrict the analysis to one investment criterion at the time, while venture capitalists combine them in the due diligence.

To overcome these problems, in this paper we use cluster analysis to classify venture capitalists in homogeneous groups depending on which factors provide the most important decision making criterion when evaluating new proposals. Our results show the existence of three groups of venture capital companies whose differences in the use of the investment criteria are significantly associated with their characteristics. In addition, the sense of the link supports the idea that the existence of asymmetric information problems might elucidate on such differences. 
We find that intuitive venture capitalists working in private companies tend to be more demanding in the application of the screening criteria during the due diligence. The strength of the screening process might arise due to increased incentives and knowledge of venture capitalists in private $\mathrm{VC}$ to obtain the information as well as higher abilities of intuitive venture capitalists to interpret qualitative information.

We use a survey dataset of 51 Spanish venture capital companies, which suits perfectly our purpose for two reasons. First of all, the heterogeneity of the Spanish venture capital sector (Carzorla et al., 1997) might give rise to differences in asymmetric information problems across venture capital companies. Second, the survey asks venture capitalists the importance they give to the most common investment criteria identified in the literature regarding the (1) entrepreneur personality and experience, (2) the characteristics of the product or service of the venture, and (3) the market of the venture.

Our paper yields two specific contributions. First, we perform a segmentation of the venture capital industry in a Continental European bank-based system. Related evidence analyzes US samples, while financial intermediation literature shows the existence of differences between the Anglo-Saxon and the Continental models in the way resources are channelled (Mayer, 1994) and the behaviour of financial intermediaries (Hernández-Cánovas and Martínez-Solano, 2010). Second, we investigate whether the existing differences in the use of the investment criteria depend on the existence of asymmetric information problems linked to specific characteristics of the venture capital companies. If the screening process is dependent on the nature of the venture capital company, it means that the same business proposal might obtain different decisions depending on the venture capital company that the entrepreneur approaches.

The paper proceeds as follows. Section 2 discusses previous research. Section 3 presents the data and method. Section 4 presents the results, and section 5 concludes.

\section{Literature review}

In an attempt to reduce the negative effects of the asymmetric information problems, venture capitalists screen out ex ante unprofitable new venture proposals applying an intensive due diligence and evaluation process (Barry, 1994; Fried and Hisrich, 1994). Existing literature suggest that asymmetric information problems as well as the ability and incentives of venture capitalists to overcome those problems are related to characteristics such as the investment strategy, the public or private origin of the resources, and the reliance on the venture capitalist intuition to evaluate the investment.

Information asymmetries confronted by public and private venture capital firms might be different for two reasons. First, Cumming and MacIntosh (2006), Brander et al. (2009) and Munari and Toschi (2010) show that unlike private venture capital funds, public ones, limited by statutory constraints, undertake projects where the main objective is to foster the economic development rather than to obtain a high profitability. Second, Lerner (2002), Leleux and Surlemont (2003) and Mason (2009) suggest that public venture capitalists are, compared to private venture capitalists, lacking in the knowledge and experience required in the screening process and due diligence of the companies. All the differences between them suggest private sector venture capitalists might be more demanding in their valuation process relative to their public counterparts.

Zacharakis and Shepherd (2001) show that intuition plays an important role when evaluating and selecting new proposals. The evaluation of soft information gathered during the due diligence makes venture capitalist's intuition a key factor of success in their decision process (Khan, 1987; MacMillan et al., 1987; Zacharakis and Shepherd, 2001; Beim and Lévesque, 2004). Intuition, which is a result of past experiences (Zacharakis and Shepherd, 2001), should increase the ability of venture capitalist to make a more demanding and complex screening process. Therefore, the consideration of a higher number of qualitative variables allows venture capitalists to reduce the asymmetric information problems (Ray, 1991; Ray and Turpin, 1993).

Existing literature suggests that differences in information asymmetries across venture capital companies are dependent on their investment strategy, i.e., the stage of development of the projects where they prefer to invest (Robinson, 1987; Florida and Kenney, 1988a, 1988b; Sapienza and Timmons, 1989; Fried and Hisrich, 1991; Bygrave and Timmons, 1992; Elango et al., 1995). Venture capital companies face higher adverse selection problems when they fund businesses in early stage of development because the firm is not consolidated and there is not verifiable and testable information about it (Ramón et al., 2007; Ferrary, 2010). As a consequence, venture capitalists evaluating projects in early stage of development are expected to be more demanding in the application of the investment criteria.

We hypothesize that the number of investment criteria and their relative importance increase with the importance of asymmetric information problems confronted by venture capitalists evaluating projects in early of 
development, with the incentives and knowledge of venture capitalists in private companies to overcome informational asymmetries, and with the ability of intuitive venture capitalists to interpret the information gather throughout the due diligence.

\section{Data and method}

\subsection{Data}

Data were obtained by means of a postal survey addressed to the 63 venture capital companies registered in the ASCRI (Asociación Española de Entidades de Capital Riesgo) in March, 2001. The design of the questionnaire benefited from valuable contributions provided by prestigious economists specialized in financial risk assessment and particularly related with the valuation of ventures. The final design of the survey was improved using interesting observations of several venture capitalists. Finally, we made a pre-test sending the questionnaire to four venture capital firms. Before sending the questionnaire we contacted the venture capital firm by telephone and identified the person in charge of the decision process. The reception of surveys was until June, 2001. We obtained 51 valid answers, which represents a response rate of $80.952 \%$.

The survey collects information about the most common selection criteria identified by previous empirical literature, representing several attributes related with three dimensions: (1) the entrepreneur personality and experience, (2) characteristics of the product or service and (3) characteristics of the market. We measure these variables using a five-point scale ( $1=$ little important; $5=$ very important). Table 1 shows that out of the ten most valued variables, eight are in the entrepreneur dimension, being their honesty and integrity (4.843) and their knowledge of the sector (4.745) the most valued variables. The other two factors in the top ten are the high growth rate of the market (4.451) and the market acceptance of the product (4.440). These data are shown in the table 1 .

In order to characterize our sample the questionnaire collects information regarding general characteristics of the venture capital companies. Table 2 shows that out of the 51 respondents in our sample, 17 (33.333\%) are "Venture Capital Firm", 18 are (35.294\%) "Venture Capital Management Company", 7 (13.726\%) are "Society of Industrial and Regional Development", and $9(17.647 \%)$ are classified as "other". The capital is private in 34 venture capital companies and public in $17.25 .490 \%$ of funds in our sample prefer the investment in early stages of development (seed or start-up financing), whereas $74.510 \%$ show a clear preference for late stages of development (post-creation or expansion financing).

\subsection{Method}

Statistical analysis is conducted using both factorial and cluster analyses, and the results are supported by means of discriminant analysis.

\subsubsection{Factor analysis}

We conduct a factor analysis in order to reduce the number of variables without loss of important information (Note 1). Table 3 shows how each of the three dimensions (entrepreneur, product and market) has been separately analyzed in order to reduce the number of variables in each one. Factors have been extracted through principal analysis and rotated by means of Varimax, with Kaiser Normalization, when it is possible. An Eigenvalue of more than 1 is used as a condition for extract factors. A correlation matrix for the factors is provided in Appendix.

The 16 variables in the entrepreneur dimension are reduced into 3 factors. The first factor, which we call entrepreneur's skills, is made up of 7 variables describing entrepreneur abilities such as attention to detail, communication skills and career in the company. The second factor, entrepreneur's personality, includes 6 variables and proxies personal characteristics of the entrepreneur such as honesty and integrity, wish to make money, and physical and mental health. In the last factor, entrepreneur's experience, among its 3 variables we highlight professional experience and knowledge of the sector.

In the product factor, which integrates the 8 variables of that dimension, the highest loadings are for the variables identification with company standards, lifecycle, and marketing strategy. As for the market factor, made up of 6 variables, we stress the importance of the variables large potential market, little early threat of competition, and market leader.

\subsubsection{Cluster analysis methodology}

Cluster analysis is a multivariate statistical method that allows us to classify our sample by reducing the data into groups with a maximal homogeneity of firms within the group, while simultaneously having a maximum heterogeneity between the groups (Hair et al., 2006). This way we are able to identify and analyze different 
classes of venture capitalists depending on the screening criteria they use to evaluate new venture investment proposals. As active variables, which are those directly involved in the formation of groups, we use the rotated factors resulting from the above factor analysis.

Following both Milligan and Sokol (1980) and Punj and Stewart (1983), we increase the stability and validity of our solution by performing a combination of cluster analysis methodologies (Hair et al., 2006).

Firstly, we use the Ward method of minimum variance, which is a hierarchical-agglomerative approach, to obtain a preliminary solution that creates the most homogeneous clusters (Bergs, 1981). In our sample, three clusters appear to be the appropriate solution.

Secondly, the $\mathrm{k}$ Means procedure is a non-hierarchical, iterative partitioning method which begins with partitioning the objects into the number of clusters given by the Ward method and subsequently, reassigning the objects to the clusters until a predetermined decision rule stops the process (Bühl and Zöfel, 2005). In our study the number of members in cluster 1 is $13(32.50 \%$ of the sample), $15(37.50 \%)$ in cluster 2 and $12(30 \%)$ in cluster 3.

\section{Results}

In this section, we first assess the internal validity of our cluster solution and next we characterize and describe each cluster.

\subsection{Validation of the cluster solution}

To assess the validation of our cluster solution, we perform a discriminant function analysis to show the existence of differences across clusters and whether the clustering factors are able to differentiate between the three groups (Morrison, 1969).

In this study, we use multivariate Wilks' lambda to evaluate the statistical significance of both the discriminant functions and the discrimination between the groups (Note 2). Wilks' lambda can take on values between zero and one (Huberty, 1994), where measures close to zero (one) are highly (low) significant. Wilks' lambda test statistic shows a value of 0.081 and, thus, high significance $(p<0.001)$ is achieved for the discriminant functions. Therefore, we can say that the cluster solution is not random and that the data can be classified into the specified groupings to a highly significant degree by the discriminant functions.

Next, when testing for the discriminatory significance of each factor in Table 4, the discriminant function analysis shows that four out of five factors ( $80 \%$ of them) significantly discriminate between the clusters. The entrepreneur's personality factor with the highest F-value (37.260) is the most capable of dividing the data into the three cluster solution; followed by the Entrepreneur's skills factor with a F-vale of 33.620.

\subsection{Description of cluster solution findings}

Table 5 displays the results obtained by applying ANOVA (analysis of variance).

We observe the existence of differences across clusters in the use of the selection criteria. All significant factors have negative coefficients in cluster 1, with the entrepreneur's personality and the market showing the lowest values among all clusters. The application of the entrepreneur's skills and the product characteristics are specially relaxed by firms in cluster 2 , while they seem to value the entrepreneur's personality more than members of cluster 1. Finally, compared to the other groups, all significant factors have the highest coefficients in cluster 3.

Next we assess whether there are cluster specific characteristics that might help us to understand the origin of the above differences in the use of the selection criteria. Characteristics such as the use of intuition, the origin of the resources and the investment strategy might influence the importance of asymmetric information problems and, therefore, explain the observed differences in the screening process.

Table 6 shows the existence of significant variations in the origin of the resources and the use of the intuition across our cluster solutions. These results seem to suggest that the application of screening criteria during the due diligence increases with the use intuition and private resources.

Firms in cluster 1, which have the most relaxed screening process, are the weakest pronounced in the use of intuition and show the highest presence of public resources. The softening in the screening process might arise due to reduced incentives to obtain the information and limited abilities to interpret it. Investments by public companies don't need to apply strict screening process to overcome asymmetric information problems because they pursue nonfinancial objectives such as political and employment goals. The lack of intuition and experience could result in uncompleted screening process due to reduced ability to interpret the information coming from 
the due diligence process.

On the contrary, cluster 3 combines the highest use of intuition with an above average presence of private resources, resulting in the most complete due diligence. It seems that skilful venture capitalists together with higher corporate incentives to gather information drive firms in this group toward more strict screening process.

Halfway between the above groups we have cluster 2, with the highest presence of private resources and a below average use of intuition, where firms apply an intermediate number of screening criteria.

\section{Conclusions}

This study examines the investment process of a sample of 51 venture capital firms in order to perform a segmentation of the venture capital industry on the basis of the most important selection criteria identified by previous empirical literature. Our results reveal the existence of a relationship between the investment criteria used in the evaluation of new business proposals and the existence of asymmetric information problems linked to the specific characteristics of the venture capital company. We find that the application of screening criteria during the due diligence increases with the use intuition and private resources. The strength of the screening process might arise due to increased incentives of private $\mathrm{VC}$ companies to obtain the information and demonstrated abilities of intuitive venture capitalists to interpret it.

This study provides a better insight into the screening process of venture capitalists and the results have clear implications for entrepreneurs and venture capital companies. Knowing what investment criteria are the most important for venture capitalists might help both entrepreneurs to elaborate better proposals, and venture capitalists to improve their decision process and achieve better survival rates.

There is one note of caution with regard to our results. Qualitative information about venture capital firms is difficult to obtain and often has to come from survey data, like in our sample. We recognize that survey data might create potential biases and possible measurement problems (Zacharakis and Meyer, 1998). However, we believe that our sample is large enough that, although cautiously, valid conclusions can be drawn.

\section{Acknowledgements}

Ginés Hernández Cánovas acknowledges financial support by Fundación Séneca (Project 15403/PHCS/10) and by Ministerio de Ciencia e Innovación (Project ECO2011-29080).

\section{References}

Backhaus, K., Erichson, B., Plinke, W., \& Weiber, R. (2006). Multivariate analyse methoden: Eine anwendungsorientierte Einführung. Berlin: Springer. ISBN-13: 978-3540850441

Barry, C. B. (1994). New directions in research on venture capital finance. Financial Management, 3(23), 3-15. http://dx.doi.org/10.2307/3665617

Beim, G., \& Lévesque, M. (2004). Selecting projects for venture capital funding: a multiple criteria decision approach. Technical Report 791, Weatherhead School of Management, Case Western University. http://citeseerx.ist.psu.edu/viewdoc/summary?doi=?doi=10.1.1.125.3397

Bergs, S. (1981). Optimalität bei Cluster Analysen. Ph.D. Thesis, University of Münster.

Brander, J., Egan, E., \& Hellmann, T. (2009). Government sponsored versus private venture capital: Canadian evidence. In J. Lerner, \& A. Shoar, (Eds.), International Differences in Entrepreneurship (pp. 275-320). [Online] Available: http://www.nber.org/papers/w14029.pdf

Bühl, A., \& Zöfel, P. (2005). SPSS 12: Einführung in die moderne datenanalyse unter Windows. München: Pearson Studium.

Bygrave, W. D., \& Timmons, J. A. (1992). Venture capital at the crossroads. Boston: Harvard Business School Press.

Carter, R. B., \& Van Auken, H. E. (1994). Venture capital firms' preferences for projects in particular stages of development. Journal of Small Business Management, 32(1), 60-74.

Cazorla, L., Céspedes, J., \& Cano, C. J. (1997). Estrategia inversora de las Entidades de Capital Riesgo: un análisis de los principales factores determinantes. Investigaciones Europeas de Dirección y Economía de la Empresa, 3(1), 77-91.

Cumming, D., \& MacIntosh, J. (2006). Crowding out private equity: Canadian evidence. Journal of Business venturing, 21, 569-609. http://dx.doi.org/10.1016/j.jbusvent.2005.06.002

Elango, B., Fried, V. H., Hisrich, R. D., \& Polonchek, A. (1995). How venture capital firms differ. Journal of 
Business Venturing, 10, 157-179. http://dx.doi.org/10.1016/0883-9026(94)00019-Q

Ferrary, M. (2010). Syndication of Venture Capital Investment: The art of resource pooling. Entrepreneurship Theory and Practice, 34(5), 885-907. http://dx.doi.org/10.1111/j.1540-6520.2009.00356.x

Florida, R., \& Kenney, M. (1988a). Venture capital and high technology entrepreneurship. Journal of Business Venturing, 3, 301-319. http://dx.doi.org/10.1016/0883-9026(88)90011-0

Florida, R., \& M. Kenney, M., (1988b). Venture capital, high technology, and regional development. Regional Studies, 22, 33-48. http://dx.doi.org/10.1080/00343408812331344750

Fried, V. H., \& Hisrich, R. D. (1991). Venture capital firms commonalities and differences. Management Research News, 14(3), 17-33. http://dx.doi.org/10.1108/eb028126

Fried, V. H., \& Hisrich, R. D. (1994). Toward a model of venture capital investment decision making. Financial Management, 23, 28-37. http://dx.doi.org/10.2307/3665619

Hair, J. F., Black, W. C., Babin, B. J., Anderson, R. E., \& Tatham, R. L. (2006). Multivariate data analysis. Upper Saddle River, NJ: Prentice Hall.

Hernández-Cánovas, G., \& Martínez-Solano, P. (2010). Relationship lending and SME financing in the continental European bank-based system. Small Business Economics, 34(4), 465-482. http://dx.doi.org/10.1007/s11187-008-9129-7

Huberty, C. J. (1994). Applied discriminant analysis. New York: John Wiley and Sons.

Khan, A. M. (1987). Assessing venture capital investments with non-compensatory behavioural decision models. Journal of Business Venturing, 2, 193-205. http://dx.doi.org/10.1016/0883-9026(87)90008-5

Leleux, B., \& Surlemont, B. (2003). Public versus private venture capital: seeding or crowding out? A pan-European analysis. Journal of Business Venturing, 18, 81-104. http://dx.doi.org/10.1016/S0883-9026(01)00078-7

Lerner, J. (2002). When bureacrats meet entrepreneurs: the design of effective "Public Venture Capital" programmes. The Economic Journal, 112(2), F73-F84. http://dx.doi.org/10.1111/1468-0297.00684

MacMillan, I. C., Zemann, L., \& SubbaNarasimha, P. N. (1987). Criteria distinguishing successful from unsuccessful ventures in the venture screening process. Journal of Business Venturing, 2, 123-137. http://dx.doi.org/10.1016/0883-9026(87)90003-6

Mason, C. (2009). Public Policy Support for the Informal Venture Capital Market in Europe: A Critical Review. International Small Business Journal, 27(5), 536-556. http://dx.doi.org/10.1177/0266242609338754

Mayer, C. (1994). The assessment: money and banking: theory and evidence. Oxford Review of Economic Policy, 10(4), 1-13. http://dx.doi.org/10.1093/oxrep/10.4.1

Milligan, G., \& Sokol, L. (1980). A two stage clustering algorithm with robust recovery characteristics. Educational and psychological measurement, 40(3), 751-755. http://dx.doi.org/10.1177/001316448004000320

Morrison, D. G. (1969). On Interpretation in Discriminant Analysis. Journal of Marketing Research, 6, 156-163. http://dx.doi.org/10.2307/3149666

Munari, F., \& Toschi, L. (2010). Assessing the impact of public venture capital programmes in the United Kingdom: Do regional characteristics matter.

Punj, G., \& Stewart, D. W. (1983). Cluster analysis in marketing research: review and suggestions for application. Journal of Marketing Research, 20(2), 134-148. http://dx.doi.org/10.2307/3151680

Ramón, T., García, D., \& Van Auken, H. E., (2007). Venture capital in Spain by stage of development. Journal of Small Business Management, 45(1), 68-88. http://dx.doi.org/10.1111/j.1540-627X.2007.00199.x

Ray, D. M. (1991). Venture capital and entrepreneurial development in Singapore. International Small Business Journal, 10(1), 11-26. http://dx.doi.org/10.1177/026624269101000101

Ray, D. M., \& Turpin, D. V. (1993). Venture capital in Japan. International Small Business Journal, 11(4), 39-56. http://dx.doi.org/10.1177/026624269301100403

Robinson, R. R. (1987). Emerging strategies in venture capital industry. Journal of Business Venturing, 2, 167-184. http://dx.doi.org/10.1016/0883-9026(87)90019-X

Sapienza, H. J., \& Timmons, J. A. (1989). The roles of venture capitalists in new ventures: what determines their importance? Academy of Management Best Paper Proceedings, 74-78. 
Zacharakis A., \& Meyer, G. (1998). A lack of insight: do venture capitalists really understand their own decision process? Journal of Business Venturing, 13, 57-76. http://dx.doi.org/10.1016/S0883-9026(97)00004-9

Zacharakis, A., \& Shepherd, D. (2001). The nature of information and overconfidence on venture capitalists' decision making. Journal of Business Venturing, 16, 311-332. http://dx.doi.org/10.1016/S0883-9026(99)00052-X

Notes

Note 1. Backhaus et al. (2006) recommend conducting a factor analysis prior to the cluster analysis in order to verify the variance of the data. The correlation matrix, the anti-image correlation matrix, and the Kaiser-Meyer-Olkin criteria are all indicators for the applicability of factor analysis in our data set.

Note 2. Multivariate Wilks' lambda applies when there are more than two clusters to validate.

Table 1. Mean and standard deviation of selection criteria

\begin{tabular}{|l|c|c|c|}
\hline & N & $\begin{array}{c}\text { Overall } \\
\text { mean }\end{array}$ & $\begin{array}{c}\text { Standard } \\
\text { Deviation }\end{array}$ \\
\hline Entrepreneur & & & \\
\hline Honesty and integrity & 51 & 4.843 & 0.367 \\
\hline Knowledge of the sector & 51 & 4.745 & 0.440 \\
\hline Professional experience & 51 & 4.686 & 0.547 \\
\hline Capacity for reaction and risk assessment & 50 & 4.580 & 0.575 \\
\hline Management team organization & 51 & 4.490 & 0.579 \\
\hline Attitude of entrepreneurship and leadership & 50 & 4.420 & 0.673 \\
\hline Familiarity with company objectives & 50 & 4.360 & 0.663 \\
\hline Capacity for intense effort & 50 & 4.240 & 0.771 \\
\hline Compatibility with venture capitalist & 50 & 4.200 & 0.926 \\
\hline Analytical ability & 48 & 3.937 & 0.809 \\
\hline Physical and mental health & 49 & 3.959 & 0.889 \\
\hline Career in the company & 49 & 3.898 & 0.822 \\
\hline Wish to make money & 48 & 3.792 & 0.921 \\
\hline Attention to detail & 49 & 3.367 & 0.809 \\
\hline Communication skills & 48 & 3.250 & 0.838 \\
\hline Search independence & 48 & 2.937 & 1.079 \\
\hline Product or service & & & \\
\hline Market acceptance & 50 & 4.440 & 0.760 \\
\hline Lifecycle & 49 & 4.143 & 0.736 \\
\hline Marketing strategy & 50 & 4.000 & 0.728 \\
\hline Patent ownership & 50 & 4.000 & 0.990 \\
\hline Functioning prototype & 46 & 3.891 & 1.016 \\
\hline Identification with company standards & 49 & 3.816 & 0.950 \\
\hline Potential overseas market & 51 & 3.667 & 0.816 \\
\hline High tech & 49 & 2.857 & 1.155 \\
\hline Market & & & \\
\hline High growth rate & 51 & 4.451 & 0.577 \\
\hline Entry barriers & 49 & 4.122 & 0.927 \\
\hline Market leader & 51 & 3.980 & 0.761 \\
\hline Large potential market & 51 & 3.961 & 0.799 \\
\hline Venture capitalist's market knowledge & 49 & 3.388 & 0.975 \\
\hline Little early threat of competition & 3.224 & 0.872 \\
\hline & & & \\
\hline
\end{tabular}


Table 2. Venture capital firms characteristics

\begin{tabular}{|l|c|c|}
\hline & $\mathrm{n}$ & $\%$ \\
\hline Type of entity & & \\
\hline Venture Capital firm & 16 & $31.372 \%$ \\
\hline Venture Capital Management Company & 18 & $35.294 \%$ \\
\hline Regional/Industrial Development Society & 7 & $13.726 \%$ \\
\hline Others & 10 & $19.608 \%$ \\
\hline Origin of the resources & 17 & \\
\hline Public & 34 & $33.333 \%$ \\
\hline Private & & $66.667 \%$ \\
\hline Intuition in decision making & 17 & $34.694 \%$ \\
\hline Little & 32 & $65.306 \%$ \\
\hline A lot & & \\
\hline Development stage & 13 & $25.490 \%$ \\
\hline Early & 38 & $74.510 \%$ \\
\hline Late & & \\
\hline
\end{tabular}

Table 3. Loadings of factor analysis

\begin{tabular}{|c|c|c|c|}
\hline \multicolumn{4}{|c|}{ Panel A. Factor loadings of variables in the entrepreneur dimension } \\
\hline & \multicolumn{3}{|c|}{ Entrepreneur's factors } \\
\hline Variable & Skills & Personality & Experience \\
\hline Career in the company & 0.767 & & \\
\hline Communication skills & 0.799 & & \\
\hline Management team organization & 0.625 & & \\
\hline Attention to detail & 0.801 & & \\
\hline Attitude of entrepreneurship and leadership & 0.606 & & \\
\hline Search independence & 0.505 & & \\
\hline Familiarity with company objectives & 0.442 & & \\
\hline Honesty and integrity & & 0.641 & \\
\hline Wish to make money & & 0.694 & \\
\hline Physical and mental health & & 0.593 & \\
\hline Compatibility with venture capitalist & & 0.549 & \\
\hline Analytical ability & & 0.385 & \\
\hline Capacity for intense effort & & 0.369 & \\
\hline Professional experience & & & 0.809 \\
\hline Knowledge of the sector & & & 0.667 \\
\hline Capacity for reaction and risk assessment & & & 0.478 \\
\hline \multicolumn{4}{|c|}{ Panel B. Factor loadings of variables in the product dimension } \\
\hline Variable & \multicolumn{3}{|c|}{ Product characteristics } \\
\hline Identification with company standards & \multicolumn{3}{|c|}{0.596} \\
\hline Lifecycle & \multicolumn{3}{|c|}{0.552} \\
\hline Marketing strategy & \multicolumn{3}{|c|}{0.542} \\
\hline Market acceptance & \multicolumn{3}{|c|}{0.342} \\
\hline High tech & \multicolumn{3}{|c|}{0.332} \\
\hline Potential overseas market & \multicolumn{3}{|c|}{0.312} \\
\hline Patent ownership & \multicolumn{3}{|c|}{0.296} \\
\hline Functioning prototype & \multicolumn{3}{|c|}{0.295} \\
\hline \multicolumn{4}{|c|}{ Panel C. Factor loadings of variables in market dimension } \\
\hline Variable & \multicolumn{3}{|c|}{ Market characteristics } \\
\hline Large potential market & \multicolumn{3}{|c|}{0.635} \\
\hline Little early threat of competition & \multicolumn{3}{|c|}{0.582} \\
\hline Market leader & \multicolumn{3}{|c|}{0.556} \\
\hline Entry barriers & \multicolumn{3}{|c|}{0.328} \\
\hline Venture capitalist's market knowledge & \multicolumn{3}{|c|}{0.328} \\
\hline High growth rate & \multicolumn{3}{|c|}{0.104} \\
\hline
\end{tabular}


Table 4. Univariate discriminatory contribution of the clustering variables

\begin{tabular}{|c|c|c|}
\hline & $\mathrm{F}$ & Sig. \\
\hline \multicolumn{3}{|l|}{ Entrepreneur } \\
\hline Entrepreneur's skills $* * *$ & 33.620 & 0.000 \\
\hline Entrepreneur's personality $* * *$ & 37.260 & 0.000 \\
\hline Entrepreneur's experience & 1.699 & 0.197 \\
\hline \multicolumn{3}{|l|}{ Product } \\
\hline Product characteristics $* * *$ & 7.797 & 0.001 \\
\hline \multicolumn{3}{|l|}{ Market } \\
\hline Market characteristics $* * *$ & 9.295 & 0.000 \\
\hline
\end{tabular}

Table 5. Active variables means by cluster

\begin{tabular}{|l|c|c|c|c|}
\hline & Mean & C1 & C2 & C3 \\
\hline Entrepreneur & & & & \\
\hline Entrepreneur's skills *** & -0.078 & -0.331 & -0.731 & 1.011 \\
\hline Entrepreneur's personality *** & -0.027 & -1.087 & 0.464 & 0.505 \\
\hline Entrepreneur's experience & 0.013 & 0.226 & -0.323 & 0.203 \\
\hline Product & & & & \\
\hline Product characteristics*** & 0.016 & -0.171 & -0.367 & 0.698 \\
\hline Market & & & & \\
\hline Market characteristics *** & 0.037 & -0.517 & 0.075 & 0.588 \\
\hline Statistical significance at the $10 \%, 5 \%, 1 \%$ level is indicated by *, **, ***, respectively \\
\hline
\end{tabular}

Table 6 . Passive variables by cluster

\begin{tabular}{|l|c|c|c|c|c|}
\hline & 1 & 2 & 3 & 4 & 5 \\
\hline 1. Entrepreneur's skills & 1 & & & & \\
\hline 2. Entrepreneur's personality & 0.099 & 1 & & & \\
\hline 3. Entrepreneur's experience & 0.035 & 0.001 & 1 & & \\
\hline 4. Product characteristics & $0.483^{* * *}$ & 0.204 & $0.297^{*}$ & 1 & \\
\hline 5. Market characteristics & $0.432 * * *$ & $0.428^{* * *}$ & 0.073 & 0.165 & 1 \\
\hline
\end{tabular}

Appendix. Correlations of the factors

\begin{tabular}{|l|c|c|c|c|}
\hline & $\mathrm{N}$ & Cluster 1 & Cluster 2 & Cluster 3 \\
\hline Origin of the resources* & & & & \\
\hline Public & $10(25 \%)$ & $6(46.154 \%)$ & $1(6.667 \%)$ & $3(25 \%)$ \\
\hline Private & $30(75 \%)$ & $7(53.846 \%)$ & $14(93.333 \%)$ & $9(75 \%)$ \\
\hline Intuition in decision making* & & & & \\
\hline Little & $12(30.769 \%)$ & $6(50 \%)$ & $5(33.333 \%)$ & $1(8.333 \%)$ \\
\hline A lot & $27(69.231 \%)$ & $6(50 \%)$ & $1066.667 \%)$ & $11(91.667 \%)$ \\
\hline Development stage & & & & \\
\hline Early & $9(22.50 \%)$ & $3(23.077 \%)$ & $3(20 \%)$ & $3(25 \%)$ \\
\hline Late & $31(77.50 \%)$ & $10(76.923 \%)$ & $12(80 \%)$ & $9(75 \%)$ \\
\hline Statistical significance at the $10 \%, 5 \%, 1 \%$ level is indicated by *, **, ***, respectively \\
\hline
\end{tabular}

